ARTIKEL PENELITIAN

\title{
GAMBARAN FAKTOR RISIKO TEKANAN DARAH SISTOLIK PADA PEKERJA TAMBANG BATU KAPUR DI KLAPANUNGGAL, BOGOR, JAWA BARAT
}

\author{
Annisa Warda Irvani $^{1}$, Mila Citrawati ${ }^{2}$, Nunuk Nugrohowati ${ }^{3}$ \\ 1. Program Studi Kedokteran, Program Sarjana, Fakultas Kedokteran Universitas Pembangunan \\ Nasional Veteran, Jakarta; 2. Departemen Ilmu Fisiologi Kedokteran, Fakultas Kedokteran Universitas \\ Pembangunan Nasional Veteran, Jakarta; 3. Departemen IImu Kesehatan Masyarakat, Fakultas \\ Kedokteran Universitas Pembangunan Nasional Veteran, Jakarta.
}

Korespondensi: Annisa Warda Irvani; alamat e-mail: annisawrdirvn@gmail.com; nomor ponsel: 087771856422

\begin{abstract}
Abstrak
Latar belakang: Prevalensi hipertensi di Kabupaten Bogor cukup tinggi, di sisi lain banyak perusahaan tambang kecil tidak memiliki fasilitas kesehatan dan jaminan kesehatan kerja bagi pekerja. Banyak faktor lingkungan pekerjaan yang dapat memengaruhi tekanan darah pekerja, namun hal ini belum diteliti pada pekerja tambang batu kapur. Tujuan: Untuk mengetahui faktor risiko yang memengaruhi tekanan darah sistolik pada pekerja tambang batu kapur di Bogor. Metode: Analitik observasional dengan desain potong lintang yang dilakukan di Klapanunggal, Bogor, terhadap 47 subjek. Hasil: Pengukuran intensitas kebisingan mesin pemecah 83,2 dB dan penghancur batu 91,7 dB. Rerata tekanan darah sistolik sebelum kerja 110,3 mmHg dan sesudah kerja 126,2 mmHg. Hasil uji One Way ANOVA menunjukkan hubungan antara intensitas kebisingan, masa kerja, durasi paparan kebisingan, dan kebiasaan merokok dengan tekanan darah sistolik $(p=0,001)$, uji regresi dummy menunjukkan intensitas kebisingan sebagai faktor yang paling berpengaruh. Perhitungan uji regresi dummy didapatkan bahwa pekerja yang terpapar kebisingan dengan intensitas $\leq 85 \mathrm{~dB}$ memiliki rerata peningkatan tekanan darah sistolik sebesar $10,45 \mathrm{mmHg}$, sementara yang terpapar intensitas $>85 \mathrm{~dB}$ sebesar 22,27 mmHg. Kesimpulan: Intensitas kebisingan, masa kerja, durasi paparan kebisingan, dan kebiasaan merokok memengaruhi tekanan darah sistolik pada pekerja tambang batu kapur.
\end{abstract}

Kata kunci: hipertensi; kebisingan; sistolik; pekerja tambang

\section{Abstract}

Background: There is a high prevalence of hypertension in Bogor Regency, where many small scale mines located. These small mines have inadequate health facilities resulting in poor occupational healthcare. These factors along with other occupational condition may predisposed workers to high blood pressure. Objective: To determine risk factors associated with systolic blood pressure in limestone miners in Klapanunggal, Bogor. Method: Observational analytic study with a cross-sectional design on 47 limestone miners. Results: The measurement of noise intensity are $83.2 \mathrm{~dB}$ on a breaker and $91.7 \mathrm{~dB}$ on a stone crusher. The average systolic blood pressure before and after work was 110.3 $\mathrm{mmHg}$ and $126.2 \mathrm{mmHg}$. The results of One-Way ANOVA test, a correlation between noise intensity, working period, prolonged exposure, and smoking habits with systolic blood pressure with $p$ value $=0.001$ was obtained. According to dummy regression test, noise intensity was the most 
influential. Workers exposed to noise with an intensity normal had an average increase $10.45 \mathrm{mmHg}$, while those exposed to an intensity abnormal $22.27 \mathrm{mmHg}$. Conclusion: Noise intensity, working period, prolonged exposure, and smoking habits are associated with systolic blood pressure in limestone miners.

Keywords: hypertension; noise; systolic; miners

\section{PENDAHULUAN}

Hipertensi merupakan salah satu penyakit berakibat fatal yang sering diabaikan oleh penderitanya karena tidak memiliki gejala khas.1 Berdasarkan data dari Sample Registration System (SRS) Indonesia pada 2014, didapatkan hipertensi sebagai penyebab kematian kelima terbesar di Indonesia.2 Menurut Riskesdas tahun 2018, Provinsi Jawa Barat menempati urutan ketujuh dari 34 Provinsi di Indonesia dengan prevalensi hipertensi sebesar 9\%.3 Kabupaten Bogor merupakan salah satu Kabupaten di Provinsi Jawa Barat dengan prevalensi penderita hipertensi sebanyak 47 ribu orang. Penyakit hipertensi erat hubungan dengan terjadinya stres fisiologis. Salah satu penyebab stres fisiologis adalah efek kebisingan.4

Pertambangan merupakan tempat segala aktivitas yang berhubungan dengan kegiatan penggalian ataupun eksploitasi barang yang ada di dalam tanah. Aktivitas pertambangan dengan menggunakan mesin dan alat berat memiliki potensi yang besar dalam menimbulkan bahaya bagi para pekerja, salah satunya kebisingan. Berdasarkan Keputusan Menteri Negara Lingkungan Hidup No. KEP48/MENLH/11/1996 tentang baku tingkat kebisingan, kebisingan adalah bunyi yang tidak diinginkan dari usaha atau kegiatan dalam tingkat dan waktu tertentu yang dapat menimbulkan gangguan kesehatan manusia dan kenyamanan lingkungan.5 Kebisingan menjadi salah satu isu global di negara maju maupun berkembang. Setiap harinya mencapai empat juta pekerja berpotensi dalam bahaya kebisingan, sementara setiap tahunnya 22 juta pekerja berpotensi terpapar bahaya kebisingan. 6 Prevalensi tenaga kerja di bidang industri yang terpapar kebisingan diperkirakan sebesar $14 \%$. Sebesar $12-15 \%$ pekerja yang terpapar bising lebih dari $85 \mathrm{~dB}$ berada di negara berkembang. Di Indonesia, pekerja yang terpapar bising lebih dari $85 \mathrm{~dB}$ mencapai 30-50\%.7

Alat-alat yang digunakan dalam setiap proses pertambangan diketahui memiliki tingkat kebisingan di atas Nilai Ambang Batas (NAB). Penelitian yang dilakukan oleh Sancini, et al menunjukkan bahwa pengukuran intensitas kebisingan yang melebihi NAB dengan waktu yang lama dapat mengakibatkan perubahan resistensi pembuluh darah tepi, denyut nadi, dan tekanan darah.8 Hasil penelitian tersebut didukung oleh Kalantary bahwa pekerja yang terpapar intensitas 
kebisingan 85-105 dB secara signifikan mengalami perubahan tekanan darah sistolik sebesar $11,7 \mathrm{mmHg}$. Hal ini disebabkan karena paparan kebisingan akan menyebabkan respon dari sistem saraf dan sistem hormon yang akan menimbulkan kecepatan denyut jantung yang berpengaruh langsung terhadap tekanan darah sistolik, namun proses ini membutuhkan waktu untuk memengaruhi tekanan darah diastolik.9

Selain kebisingan, kebiasaan merokok juga memiliki pengaruh pada peningkatan tekanan darah. Menurut data Tobacco Control Support Center tahun 2015 konsumsi rokok di Indonesia masih cenderung tinggi, rata-rata perorang dapat menghabiskan 12,3 batang per hari.10 Merokok dapat mengakibatkan peningkatan tekanan darah yang diakibatkan oleh zat-zat kimia yang terkandung di dalam tembakau. Zat-zat tersebut akan merusak lapisan dinding arteri, sehingga arteri menjadi lebih rentan terjadi penumpukan plak (arterosklerosis). Hal utama disebabkan oleh nikotin yang akan merangsang saraf simpatis sehingga kerja jantung meningkat dan menyebabkan penyempitan pembuluh darah, serta karbonmonoksida yang dapat menggantikan peran oksigen dalam darah dan memaksa jantung memenuhi kebutuhan oksigen tubuh.

Klapanunggal, salah satu daerah di Kabupaten Bogor, merupakan lokasi beberapa perusahaan tambang kecil, termasuk tambang batu kapur, yang tidak memiliki fasilitas kesehatan sehingga, tidak ada jaminan kesehatan kerja bagi para pekerja. Selain itu, sebagian besar penelitian yang sudah dilakukan pada pekerja tambang batu kapur hanya berfokus pada sistem pernafasan sehingga penelitian terkait gambaran faktor risiko terhadap tekanan darah belum banyak diteliti. Beberapa penelitian yang sudah dilakukan juga belum menunjukkan bahwa terdapat faktor lain yang dapat berpengaruh pada tekanan darah sistolik seperti durasi paparan kebisingan dan masa kerja. Oleh karena itu, penelitian ini dilakukan untuk mengetahui faktor apa saja yang berhubungan dengan tekanan darah sistolik pada pekerja tambang batu kapur di Klapanunggal, Bogor.

\section{METODE}

Jenis penelitian yang digunakan adalah analitik observasional dengan melakukan pengukuran variabel independen dan dependen untuk menjelaskan hubungan kausal antara variabel melalui pengujian hipotesis. ${ }^{11}$ Pendekatan yang digunakan adalah desain cross-sectional yaitu pengambilan variabel dependen dan independen dilakukan pada satu waktu yang bersamaan. ${ }^{12}$

Populasi dalam penelitian berjumlah 47 orang, yang merupakan seluruh pekerja tambang batu kapur di Klapanunggal, Gunung Putri, Kabupaten Bogor, Provinsi Jawa Barat yang memenuhi kriteria: lakilaki, usia 25-55 tahun, memiliki tekanan darah normal (sistolik $<120 \mathrm{mmHg}$ dan diastolik $<80 \mathrm{mmHg}$ ), indeks massa tubuh (IMT) <23, tidak memiliki riwayat 
hipertensi, serta bersedia menandatangani lembar persetujuan (informed consent).

Sumber data merupakan data primer yang diperoleh menggunakan kuesioner untuk mengetahui karakteristik subjek, intensitas kebisingan diukur dengan menggunakan sound level meter GM 1352 selama waktu kerja, dan tekanan darah diukur dengan sfigmomanometer digital OMRON HEM 7130.

Analisis statistik dilakukan menggunakan uji One Way ANOVA dan uji regresi dummy, kemaknaan statistik dicapai apabila nilai $p<0,05$.

\section{HASIL DAN PEMBAHASAN}

\section{Karakteristik subjek}

Karakteristik subjek meliputi umur, IMT, konsumsi alkohol, kopi, makanan berlemak, dan makanan gurih/asin. Distribusi responden menurut karakteristik tersebut dapat dilihat pada Tabel 1. Data menunjukan bahwa distribusi umur terbanyak adalah 26 - 45 tahun atau tergolong dewasa. Sebagian besar subjek memiliki IMT normal. Sebagian besar subjek tidak mengonsumsi alkohol. Mayoritas subjek mengonsumsi kopi, makanan berlemak, dan makanan gurih/asin.
Tabel 1. Karakteristik pekerja tambang batu kapur $(n=47)$

\begin{tabular}{|c|c|c|c|}
\hline No. & $\begin{array}{l}\text { Karakteristik } \\
\text { responden }\end{array}$ & $\mathbf{n}$ & $\%$ \\
\hline \multirow[t]{3}{*}{1.} & Umur (tahun) & & \\
\hline & $26-45$ & 36 & 76,6 \\
\hline & $46-65$ & 11 & 23,4 \\
\hline \multirow[t]{3}{*}{2.} & IMT (kg/m²) & & \\
\hline & Underweight & 7 & 14,9 \\
\hline & Normal & 40 & 85,1 \\
\hline \multirow[t]{3}{*}{3.} & $\begin{array}{l}\text { Mengonsumsi } \\
\text { alkohol }\end{array}$ & & \\
\hline & $\mathrm{Ya}$ & 19 & 40,4 \\
\hline & Tidak & 28 & 59,6 \\
\hline \multirow[t]{3}{*}{4.} & $\begin{array}{l}\text { Mengonsumsi } \\
\text { kopi }\end{array}$ & & \\
\hline & $\mathrm{Ya}$ & 43 & 91,5 \\
\hline & Tidak & 4 & 8,5 \\
\hline \multirow[t]{3}{*}{5.} & $\begin{array}{l}\text { Mengonsumsi } \\
\text { makanan } \\
\text { berlemak }\end{array}$ & & \\
\hline & $\mathrm{Ya}$ & 44 & 93,6 \\
\hline & Tidak & 3 & 6,4 \\
\hline \multirow[t]{4}{*}{6.} & Mengonsumsi & & \\
\hline & makanan & 43 & 91,5 \\
\hline & $\begin{array}{l}\text { gurih/asin } \\
\mathrm{Ya}\end{array}$ & 4 & 8,5 \\
\hline & Tidak & & \\
\hline
\end{tabular}

Faktor risiko okupasi yang dapat mempengaruhi tekanan darah

Pada Tabel 2 disajikan distribusi faktor risiko okupasi yang dapat mempengaruhi tekanan subjek. Separuh subjek terpapar kebisingan dalam batas normal ( $\leq 85 \mathrm{~dB}$ ). Sebagian besar subjek telah bekerja selama kurang dari 5 tahun dan setiap hari bekerja $\leq 8$ jam. Kebiasaan merokok dapat diklasifikasikan menjadi derajat merokok berdasarkan indeks Brinkman. Hasil perhitungan indeks Brinkman didapatkan, bahwa sebagian besar subjek tergolong perokok ringan (0 - 199 batang). 
Tabel 2. Distribusi faktor risiko okupasi yang dapat mempengaruhi tekanan darah pada pekerja tambang batu kapur $(n=47)$

\begin{tabular}{clcc}
\hline No. & Faktor risiko & $\mathbf{n}$ & $\%$ \\
\hline 1. & $\begin{array}{l}\text { Intensitas } \\
\text { kebisingan }\end{array}$ & & \\
& $\leq 85 \mathrm{~dB}$ & 24 & 51.1 \\
& $>85 \mathrm{~dB}$ & 23 & 48.9 \\
2. & Masa kerja & & \\
& $<5$ tahun & 29 & 61.7 \\
& $\geq 5$ tahun & 18 & 38.3 \\
3. & $\begin{array}{l}\text { Durasi } \\
\text { paparan }\end{array}$ & & \\
& & \\
& kebisingan & & \\
& $\leq 8$ jam & 24 & 51.1 \\
& $>8$ jam & 23 & 48.9
\end{tabular}

4. Kebiasaan

\section{Merokok}

$\begin{array}{lcc}\text { Ringan } & 28 & 59.6 \\ \text { Sedang } & 13 & 27.6 \\ \text { Berat } & 6 & 12.8\end{array}$

Pengukuran intensitas kebisingan
dilakukan selama waktu kerja yakni delapan jam pada dua tempat yang berbeda yaitu pada unit kerja breaker dan stone crusher. Kebisingan di pertambangan batu kapur diperoleh dari suara mesin serta alat berat dari proses pemecahan dan penghancuran batu. Intensitas kebisingan pada dua unit kerja pertambangan batu kapur yakni breaker sebesar 83,2 dB dan stone crusher sebesar 91,7 dB. Penelitian ini menunjukkan bahwa lebih banyak pekerja tambang yang terpapar kebisingan dengan intensitas dalam batas normal $\leq 85$ dB. Hal ini berbeda dengan hasil penelitian Montolalu pada tahun 2013 yang menunjukkan bahwa kebanyakan pekerja lapangan di PT. Gapura Angkasa di Bandar Udara Sam Ratulangi, Manado, terpapar kebisingan melebih NAB yaitu sebesar $73,3 \%{ }^{13}$

Masa kerja tenaga kerja dikategorikan menjadi dua yaitu lebih dari sama dengan 5 tahun dan kurang dari 5 tahun berdasarkan waktu dalam satu periode surat izin pertambangan. Berdasarkan penelitian ini terdapat 29 orang $(61,7 \%)$ yang sudah bekerja di area pertambangan selama $<5$ tahun terhitung dari awal bekerja sampai penelitian ini berlangsung, sedangkan pekerja tambang sudah bekerja selama $\geq 5$ tahun sebanyak 18 orang (38,3\%). Berdasarkan masa kerja mayoritas baru responden memiliki masa kerja $<5$ tahun. Kondisi ini berbeda dengan penelitian yang dilakukan oleh Widya pada tahun 2018 bahwa mayoritas responden dalam penelitiannya $(58,1 \%)$ telah bekerja $\geq 5$ tahun. ${ }^{14}$

Berdasarkan hasil dari penelitian ini, diketahui bahwa mayoritas pekerja tambang terpapar kebisingan $\leq 8$ jam dalam satu hari yaitu sebanyak 24 orang $(51,1 \%)$, sedangkan pekerja yang terpapar kebisingan $>8$ jam sebanyak 23 orang $(48,9 \%)$. Hasil ini berbeda dengan penelitian Montolalu pada tahun 2013 yang seluruh respondennya (100.0\%) terpapar kebisingan $>8$ jam. ${ }^{13}$

Berdasarkan hasil dari penelitian ini, didapatkan bahwa sebagian besar pekerja tambang masuk kategori perokok ringan berdasarkan indeks Brinkman sebanyak 28 orang (59,6\%), sedangkan pekerja tambang dengan kategori perokok sedang 
sebanyak 13 orang $(27,6 \%)$ dan 6 orang lainnya (12,8\%) masuk kategori perokok ringan. Hasil penelitian ini berbeda dengan penelitian Tawbariah $L$, et al pada tahun 2013 yang menunjukkan bahwa mayoritas respondennya masuk kategori perokok berat $(55,7 \%) .{ }^{15}$

\section{Tekanan darah sistolik}

Hasil pengukuran tekanan darah sistolik pada pekerja tambang batu kapur sebelum dan sesudah bekerja disajikan pada Tabel

3. Tampak adanya kenaikan tekanan darah sistolik setelah bekerja.

Tabel 3. Tekanan darah sistolik sebelum dan sesudah kerja $(n=47)$

\section{Rerata tekanan darah sistolik $(\mathrm{mmHg})$}

Sebelum kerja Sesudah kerja

$110.3 \quad 126.2$

\section{Analisis One Way ANOVA}

Berdasarkan didapatkan hasil bahwa intensitas kebisingan, masa kerja, durasi paparan kebisingan, dan kebiasaan merokok memiliki pengaruh terhadap tekanan darah sistolik ( $R=0.716 ; F=11.034$; $p=0,001)$. Hasil penelitian ini sejalan dengan penelitian Montolalu pada tahun 2013 bahwa intensitas kebisingan berpengaruh secara signifikan terhadap tekanan darah sistolik dengan nilai $\mathrm{p}=0,018$ ( $p<0,05) \cdot{ }^{13}$ Berbeda dengan penelitian yang dilakukan oleh Widya pada tahun 2018 yang menunjukkan tidak terdapat pengaruh antara masa kerja dengan tekanan darah sistolik dan tidak terdapat pengaruh durasi paparan kebisingan terhadap tekanan darah sistolik. ${ }^{14}$ Namun, hasil penelitian ini sejalan dengan penelitian Tawbariah L et al (2013) yang menunjukkan bahwa terdapat hubungan yang bermakna antara konsumsi rokok dengan peningkatan tekanan darah sistolik. ${ }^{15}$

Kebisingan melebihi NAB dapat menyebabkan penyempitan pembuluh darah dan gangguan organ jantung. Pengaturan tekanan ini bergantung pada kontrol dari kedua penentu utama yaitu curah jantung dan resistensi perifer total. Jika kecepatan denyut jantung meningkat akan memberi pengaruh pada tekanan darah sistolik, sementara itu resistensi perifer total berpengaruh pada tekanan darah diastolik. Paparan kebisingan akan direspon sebagai stresor oleh sistem saraf sehingga merangsang pengeluaran hormon yang akan menimbulkan kecepatan denyut jantung serta memberi pengaruh langsung terhadap tekanan darah sistolik, namun hal tersebut membutuhkan waktu untuk memengaruhi terhadap tekanan darah diastolik. ${ }^{14}$

Hormon norepinefrin akan berikatan dengan reseptor $\alpha_{2}$ yang ada di pembuluh darah menyebabkan diameter arteri mengecil sehingga terjadi peningkatkan resistensi perifer total, sementara epinefrin akan berikatan pada reseptor $\boldsymbol{\beta}_{1}$ di jantung yang memengaruhi kontraktilitas sehingga menyebabkan peningkatkan denyut jantung yang 
selanjutnya diikuti oleh peningkatan curah jantung sehingga terjadi peningkatan tekanan darah. ${ }^{16,17}$

Masa kerja berperan sebagai faktor pendorong. Seluruh paparan kebisingan yang diterima oleh pekerja akan memicu sistem saraf dan pengeluaran hormon yang dapat meningkatkan tekanan darah terutama tekanan darah sistolik yang memiliki sifat lebih sensitif. Ketika tekanan darah terus meningkat dalam jangka waktu yang lama dan terus-menerus dapat membuat tubuh beradaptasi sehingga menghasilkan kenaikan tekanan darah yang semakin tinggi serta menetap. Durasi paparan kebisingan dapat menjadi salah satunya faktor risiko yang menyebabkan peningkatan tekanan darah sistolik. Gangguan akibat kebisingan akan timbul setelah bekerja secara kontinyu selama bertahun-tahun di tempat kerja yang terpapar kebisingan. Hal tersebut dapat membuktikan bahwa durasi paparan kebisingan erat pula kaitannya dengan masa kerja.

Salah satu kandungan dalam rokok yaitu nikotin akan merangsang sistem saraf simpatik, ujung saraf tersebut akan melepaskan merangsang untuk melepaskan sistem humoral kimia, yaitu norepinefrin melalui saraf adrenergik dan meningkatkan katekolamin yang dikeluarkan oleh medula adrenal. Selanjutnya secara cepat norepinefrin akan berikatan dengan reseptor $\alpha_{2}$ yang terdapat di pembuluh darah menyebabkan vasokonstriksi pembuluh darah sehingga menghalangi arus darah secara normal, menyebabkan aliran darah berkurang. Menurut hukum Poiseuille, volume darah dan jumlah kapasitas pembuluh darah berbandung lurus. Jika terjadi perubahan diameter pembuluh darah (vasokonstriksi) maka akan terjadi perubahan pada nilai osmotik dan tekanan hidrostatik di dalam vaskuler serta ruang-ruang intersisial di luar pembuluh darah. Tekanan hidrostatik dalam vaskuler akan meningkat, sehingga tekanan darah sistolik juga akan meningkat. ${ }^{18}$

\section{Analisis Multivariat}

Pemilihan variabel bebas dalam analisis multivariat dilakukan melalui seleksi pada analisis bivariat dengan uji regresi dummy. Variabel bebas dapat dimasukkan ke dalam permodelan multivariat jika hasil analisis memiliki nilai $p<0,025$. Setelah dilakukan uji statistik regresi dummy maka diperoleh hasil disajikan pada Tabel 4. Variabel masa kerja, durasi paparan kebisingan, dan kebiasaan merokok tidak dapat dimasukkan ke dalam analisis multivariat disebabkan nilai nilai $p>0,025$ sehingga dapat disimpulkan bahwa dari keempat variabel bebas (intensitas kebisingan, masa kerja, durasi paparan kebisingan, dan kebiasaan merokok) yang berpengaruh dominan pada tekanan darah sistolik adalah intensitas kebisingan dengan $p=0,001$. 
Tabel 4. Seleksi variabel

\begin{tabular}{clc}
\hline No. & Variabel bebas & $\begin{array}{c}\text { Nilai } \\
\text { p }\end{array}$ \\
\hline 1. & Intensitas kebisingan & 0,001 \\
2. & Masa kerja & 0,446 \\
3. & Durasi paparan kebisingan & 0,970 \\
4. & Kebiasaan merokok & 0,322 \\
\hline
\end{tabular}

Hasil perhitungan uji regresi dummy dengan menggunakan rumus $\mathrm{Y}=\mathrm{B}+\mathrm{B}_{1} \mathrm{X}_{1}$ (Tabel 5) menunjukkan bahwa pekerja tambang batu kapur yang terpapar kebisingan dengan intensitas dalam batas normal yaitu $\leq 85 \mathrm{~dB}$ selama waktu kerja memiliki rata-rata peningkatan tekanan darah sistolik sebesar 10,45 $\mathrm{mmHg}$. Sementara itu, pekerja tambang batu kapur yang terpapar kebisingan dengan intensitas melebihi nilai ambang batas (>85 dB) memiliki rata-rata peningkatan tekanan darah sistolik sebesar 22,27 $\mathrm{mmHg}$.

Tabel 5. Perhitungan regresi dummy

\begin{tabular}{lcccc}
\hline $\begin{array}{l}\text { Variabel } \\
\text { bebas }\end{array}$ & \multicolumn{2}{c}{ Nilai } & \multicolumn{2}{c}{ Kategori } \\
& B & $\mathrm{B}_{1}$ & $\leq 85 \mathrm{~dB}$ & $>85 \mathrm{~dB}$ \\
\hline $\begin{array}{l}\text { Intensitas } \\
\text { kebisingan }\end{array}$ & 10.45 & 11.82 & 0 & 1 \\
\hline
\end{tabular}

Hasil ini serupa dengan penelitian yang dilakukan oleh Siswati dan Retno (2017) yang mendapatkan bahwa intensitas kebisingan merupakan variabel yang paling berpengaruh pada tekanan darah sistolik pada pekerja industri kemasan semen dengan rata-rata peningkatan 11,59 mmHg. ${ }^{19}$ Pengaruh kebisingan terhadap tekanan darah dapat dijelaskan oleh respon stres dari kebisingan yang diteruskan ke sistem saraf pusat yaitu hipotalamus bagian prefrontal, lalu ke medula adrenal, sehingga katekolamin berupa norepinefrin yang disekresi berpengaruh pada peningkatan resistensi total perifer dan epinefrin yang berpengaruh pada peningkatan denyut jantung. Selain itu, medula adrenal juga menginervasi aparatus juksta glomerular secara langsung untuk menghasilkan hormon renin yang akan mengaktivasi sistem renin-angiotensin-aldosteron yang berpengaruh pada peningkatan isi sekuncup. Peningkatan isi sekuncup dan denyut jantung akan meningkatkan curah jantung yang selanjutnya akan terjadi peningkatan tekanan darah. ${ }^{16,17,20}$

\section{KESIMPULAN}

Terdapat hubungan antara intensitas kebisingan, masa kerja, durasi paapran kebisingan, dan kebiasaan merokok dengan tekanan darah sistolik pada pekerja tambang batu kapur di Klapanunggal, Gunung Putri, Kabupaten Bogor, Provinsi Jawa Barat. Faktor intensitas kebisingan merupakan faktor yang paling berpengaruh terhadap tekanan darah sistolik pada pekerja tambang tersebut.

\section{DUKUNGAN FINANSIAL}

Penulis tidak mendapat dukungan finansial dari pihak manapun dalam penelitian ini. 


\section{UCAPAN TERIMA KASIH}

Penulis mengucapkan terimakasih atas kesediaan seluruh pekerja tambang batu kapur Klapanunggal yang bersedia menjadi subjek dalam penelitian ini.

\section{KONFLIK KEPENTINGAN}

Penulis tidak memiliki konflik kepentingan apapun terkait penelitian ini.

\section{DAFTAR PUSTAKA}

1. Rilantono L. Penyakit Kardiovaskular (PKV): 5 Rahasia. Jakarta: Fakultas Kedokteran Universitas Indonesia; 2012.

2. System SR. Indonesia Sample Registrasion System - Deaths 2014. 2014; Available from: http://ghdx.healthdata.org/record/indonesia-sample-registration-system-deaths-2014

3. RI BK. Badan Penelitian dan Pengembangan Kesehatan Kementerian RI tahun 2018. 2018; Available

from:

http://www.depkes.go.id/resources/download/infoterkini/materi_rakorpop_2018/Hasil

Riskesdas 2018.pdf

4. Suma'mur P. Higiene Perusahaan dan Kesehatan Kerja. Jakarta: Sagung Seto; 2013.

5. Indonesia KMLH. Keputusan Menteri Negara Lingkungan Hidup No. Kep-48/MENLH/11/1996 Tentang Baku Tingkat Kebisingan Sekretariat Negara. 1996; Available from: http://jdih.dephub.go.id/assets/uudocs/permen/2005/km_no_15_tahun_2005.pdf

6. NIOSH. Centers for Disease Control and Prevention (CDC). 2015; Available from: http://www.cdc.gov/niosh/topics/no ise/stats.html

7. Hakim L. Evaluasi Faktor Kebisingan yang Mempengaruhi Kesehatan dan Keselamatan Kerja dan Mempengaruhi Performansi Kerja (Studi Kasus: PT. Aneka Tambang Emas Pongkor Tbk [Internet]. Universitas Muhammadiyah Surakarta; 2010. Available from: http://eprints.ums.ac.id/10338/

8. Sancini A, Caciari R, lannottone M, Loreti B, Scala B, Sacco C, et al . Can Noise Cause High Blood Pressure? Occupational Risk in Paper Industry. J Clin Ter [Internet]. 2014;165(4):304-11. Available from: https://www.ncbi.nlm.nih.gov/pubmed/25203347

9. Kalantary S, Dehghani A, Yekaninejad MS, Omidi L, Rahimzadeh M. The effects of occupational noise on blood pressure and heart rate of workers in an automotive parts industry. ARYA Atheroscler [Internet]. 2015;11(4):215-9. Available from: https://www.ncbi.nlm.nih.gov/pubmed/25203347

10. TCSC. Tobacco Control Support Centre Indonesia. 2015; Available from: https://www.tcscindonesia.org/health-3/

11. Dahlan M. Langkah-Langkah Membuat Proposal Penelitian Bidang Kedokteran dan Kesehatan. 2nd ed. Jakarta: Sagung Seto; 2012.

12. Notoatmodjo S. Metodologi Penelitian Kesehatan. Jakarta: Rineka Cipta; 2012.

13. Montolalu SS. Hubungan Kebisingan Terhadap Tekanan Darah Pada Pekerja Lapangan PT. Gapura Angkasa Di Bandar Udara Sam Ratulangi. J e-Biomedik Univ Sam Ratulangi [Internet]. 2014;2(1). Available from: https://doi.org/10.35790/ebm.2.1.2014.3643 
14. M Widya. Hubungan Intensitas Kebisingan dengan Tekanan Darah Sistolik dan Diastolik Pada Pekerja Pertambangan Pasir dan Batu PT. X Rowosari Semarang. J Kesehat Masy [Internet]. 2018;6(6):225-34. Available from: http://ejournal3.undip.ac.id/index.php/jkm

15. L Tawbariah, Apriliana E, Wintoko R, A Sukohar. The Corelation of Consuming Cigarette with Blood Pressure of The Society in Pasaran Island Kota Karang Village East Teluk Betung SubDistrict Bandar Lampung. Med J Lampung Univ [Internet]. 2014;3(6). Available from: https://juke.kedokteran.unila.ac.id/index.php/majority/article/view/293

16. Sherwood L. Fisiologi Manusia dari Sel ke Sistem. 8th ed. Jakarta: EGC; 2014.

17. Guyton A, Hall J. Buku Ajar Fisiologi Kedokteran. 12th ed. Jakarta: EGC; 2014.

18. Irza S. Analisis Faktor Risiko Hipertensi pada Masyarakat Nagari Bungo Tanjung Sumatera Barat. Skripsi Progr Stud IImu Farm Univ Sumatera Utara [Internet]. 2009; Available from: https://text-id.123dok.com/document/myjdj95y-analisis-faktor-risiko-hipertensi-padamasyarakat-nagari-bungo-tanjung-sumatera-barat.html

19. Siswati S, Adriyani R, . Hubungan Pajanan Kebisingan dengan Tekanan Darah dan Denyut Nadi pada Pekerja Industri Kemasan Semen. J Kesehat Lingkung Indones [Internet]. 2017;16(1):2936. Available from: https://doi.org/10.14710/jkli.16.1.29-36

20. Ganong W. Buku Ajar Fisiologi Kedokteran. 25th ed. Jakarta: EGC; 2016. 